DOI: 10.31392/NPU-nc.series14.2019.27.16

УДК 378:014:78

Гао Мін

\title{
Педагогічний потенціал фахового навчання для формування вокально-виконавського досвіду майбутніх учителів музичного мистецтва
}

\begin{abstract}
Розглядається проблематика потенціальних можливостей і резервів фахового навчання студентів факультетів мистецтв педагогічних університетів. Формування вокально-виконавського досвіду в майбутніх вчителів музичного мистецтва вимагає упровадження педагогічних орієнтирів у процес фахового навчання, серед яких: інтегративний підхід; привнесення у навчальні дисципліни, які не володіють можливостями безпосередньої вокально-виконавської діяльності, вокально-виконавського елементу; цілеспрямованість процесу фахового навчання майбутніх учителів музичного мистецтва на педагогічну мобілізацію всіх можливих резервів навчальних курсів. Педагогічний потенціал фахового навчання майбутніх учителів музичного мистецтва щодо формування вокально-виконавського досвіду в якості комплексу педагогічних можливостей цього процесу визначається через методичний інструментарій вмотивованості студентів у систематичному провадженні вокально-виконавської діяльності як основного джерела вокально-виконавського досвіду, а також через акумуляцію знань, умінь і навичок, необхідних для розвитку інтелектуально-творчих особистісних якостей, що забезпечують стабільний якісний рівень вокального виконавства.

Ключові слова: вокально-виконавська діяльність; досвід; комплекс педагогічних можливостей; педагогічні орієнтири; студенти факультетів мистецтв педагогічних університетів; функції фахового навчання.
\end{abstract}

На сьогоднішньому етапі поглиблення структурних реформ вищої школи, постійного оновлення змісту світових освітніх процесів у напрямку підвищення якості навчання з метою надання майбутнім фахівцям все більшої кваліфікованості, роботодавці бажають працевлаштовувати таких молодих фахівців, які вже із студентської лави отримали певний досвід професійної діяльності. Згідно з Національною доктриною розвитку освіти України основним завданням вищої освіти $є$ підвищення рівня фахової підготовки педагогічних кадрів, що передбачає набуття студентами у ВНЗ означеного досвіду. Це у повній мірі стосується й директорів сучасних закладів повної середньої освіти, що бажають працевлаштувати такого вчителя музичного мистецтва, який здатен на належному рівні провадити із учнями вокально-хорову роботу, очолювати різні форми організації колективного музикування школярів (шкільні хорові колективи, вокальні ансамблі тощо), за допомогою котрих шкільні святкові заходи набувають творчого забарвлення, а також здатен вести власну просвітницьку вокально-виконавську діяльність. Відповідати означеним вимогам може тільки такий випускник музично-педагогічного ВНЗ, який вже має власний досвід вокально-виконавської діяльності.

Саме тому професорсько-викладацький склад музично-педагогічних ВНЗ постійно знаходиться у пошуку нових резервів у процесі фахового навчання щодо різних форм організації практичної вокально-виконавської діяльності, на базі якої формується фонд вокально-виконавського досвіду майбутніх учителів музичного мистецтва. Це засвідчує сучасну тенденцію зростання актуальності проблематики потенціальних можливостей $\mathrm{i}$ резервів фахового навчання студентів факультетів мистецтв педагогічних університетів для формування вокально-виконавського досвіду, що й обумовило вибір теми цього дослідження.

Мета статті - дослідити, теоретично обгрунтувати й сформулювати визначення педагогічного потенціалу фахового навчання майбутніх учителів музичного мистецтва для формування вокально-виконавського досвіду.

Проблема досвіду музичного виконавства була ретельно досліджена такими науковцями у царині музичної педагогіки та виконавства, а також педагогами у галузі практичного музичного виконавства, як Л.Бонфельд, І.Дікун, Т.Завадська, А.Зданович, А.Козир, 
В.Крицький, Л.Куненко, Г.Нейгауз, Г.Падалка, О.Рудницька, Г.Стулова, О.Хоружа, В.Шульгіна, О.Щолокова, Б.Яворський та ін. Означені автори не просто наполягають на важливості проблеми набуття досвіду музично-творчої виконавської діяльності майбутніх учителів музики для їх подальшої роботи, але й зазначають про те, що набуття означеного досвіду стимулює загальний інтелектуально-творчий розвиток особистості студента. Ми повністю погоджуємось із В.Крицьким, який стверджує, що досвід музичного виконання спричиняє до активізації музично-творчих можливостей студентів. Дослідник зазначає, що «...художньо-творчий розвиток відбувається в ході накопичення музично-виконавського досвіду...» [3, 200].

Науковці, що працюють безпосередньо у галузі теорії й методики постановки голосу, педагоги-вокалісти також активно розробляли проблематику досвіду вокально-виконавської діяльності. До цієї проблеми долучились В.Антонюк, Д.Аспелунд, А.Дмитрієв, Т.Жигінас, О.Матвєєва, О.Менабені, О.Микиша, П.Органов, Є.Проворова, Л.Тоцька, С.Юдін та ін. Осмислюючи процес вокального виконавства в якості творчої діяльності, детермінованої часом, необхідним для відтворення того чи іншого вокального жанру, яке відбувається шляхом залучення співацького голосу засобами вокальної майстерності, ми визначаємо «вокально-виконавський досвід» як особистісно-фахову характеристику майбутнього вчителя музичного мистецтва, що синтезує знання, уміння й навички у царині вокального виконавства, здатність до оцінювання й рефлексивного аналізу результатів як власної вокально-виконавської діяльності, так і концертних виступів інших вокалістів, а також спроможність щодо врахування й корегування допущених помилок.

У сучасних концепціях фахового навчання майбутнього вчителя музики велику роль відіграють дослідження, які розглядають формування досвіду фахової діяльності у цілому як інтегративної, багатоаспектної та поліхудожньої (А.Болгарський, І.Дікун, А.Козир, Г.Падалка, О.Ростовський, О.Рудницька та ін.). В науковому обгрунтуванні структури фахового навчання студентів факультетів мистецтв педагогічних університетів особливу роль відводять також музично-виконавській діяльності, яка є важливим чинником професійної компетентності майбутнього вчителя музичного мистецтва (Ван Їсін, Ван Лей, Лі Чуньпен, О.Матвєєва, Л.Тоцька та ін.). У той же час, проблематика педагогічного потенціалу фахового навчання майбутніх учителів музичного мистецтва саме для формування вокальновиконавського досвіду не отримала, на нашу думку, належного висвітлення й розв'язання, незважаючи на те, що саме у процесі фахового навчання закладаються підвалини щодо набуття вокально-виконавського досвіду як однієї з основ професійної компетентності майбутнього вчителя музичного мистецтва.

Для визначення педагогічного потенціалу фахового навчання щодо формування в студентів факультетів мистецтв педагогічних університетів вокально-виконавського досвіду доцільним $є$ розгляд ролі й значення освітніх процесів мистецтва у формуванні досвіду особистості, що представлено вже у творах античних мислителів (Сократ, Архімед), у філософських трактатах епохи Відродження та Просвітництва, зокрема, українських (Л.Баранович, І.Галятовський, І.Гізель, Г.Кониський, Й.Кононович-Горбацький, Ф.Прокопович, Ст.Яворський та ін.) [1]. Велику увагу ролі освітніх процесів у формування досвіду особистості приділяли у своїх філософсько-естетичних працях представники німецької класичної філософії І. Кант, Г. В. Ф. Гегель та ін.

Зокрема, представники німецької класичної філософії висвітлили педагогічний аспект питання щодо ролі й значення мистецької освіти у становленні досвіду особистості. Причому характерним для вивчення мистецтва, на думку філософів, $\epsilon$ те, що мистецька освіта, стимулюючи емоційний та інтелектуальний розвиток індивіда, сприяє його залученню не тільки до того чи іншого різновиду мистецького досвіду, але й до загальнолюдського досвіду [4].

Адже потенційна духовна цінність мистецької освіти загалом і фахового навчання майбутніх учителів музичного мистецтва реалізується тільки тоді, коли результати мистецького навчання органічно включені в як у фаховий, так і у життєвий досвід майбутнього фахівця- 
музиканта, який стає художньо-образним інструментом пізнання дійсності, а також іiі конкретно-чуттєвим відтворенням у процесі музичної творчої діяльності [5].

Педагогічний потенціал фахового мистецького навчання щодо формування в студентів факультетів мистецтв педагогічних університетів вокально-виконавського досвіду залучає функції музичного мистецтва загалом і функції мистецтва вокального виконавства зокрема, актуалізація яких у процесі фахового навчання здійснює художньо-естетичний вплив музичного мистецтва на особистість майбутнього фахівця.

Зв’язок вокально-виконавської і педагогічної діяльності дозволяє стверджувати про поглиблення зазначеного впливу під час цілеспрямованого формування вокальновиконавського досвіду студентів на базі сукупності функцій музичного мистецтва, до якої належать: художня, гедоністична, ілюстративна, пізнавальна, комунікативна, виховна. 3 цими функціями корелюють функції безпосередньо мистецької освіти, конкретизовані Г.Падалкою, а саме: мотиваційно-виховна, культурологічна, пізнавальна, гедоністична, комунікативна, творчо-спонукальна, а також функція психологічної розрядки [6, 7-29].

Визначення педагогічного потенціалу фахового навчання щодо формування в студентів факультетів мистецтв педагогічних університетів вокально-виконавського досвіду передбачає розуміння комплексного впливу на особистість наведених вище функцій [7], адже ізольований підхід до розгляду вищезазначених функцій в процесі вокально-виконавської діяльності може призвести до обмеженості художнього мислення, вузькості образноасоціативних уявлень, недостатньої наукової компетентності у розумінні стильової атрибутики виконуваних вокальних творів [8].

Зміст фахового навчання майбутніх учителів музичного мистецтва, які здобувають кваліфікаційний рівень бакалавра, відносно до можливостей практичної вокальновиконавської діяльності як основного джерела набуття досвіду вокального виконавства включає наступні навчальні курси: «Постановка голосу», «Спецкурс 3 постановки голосу», «Хоровий клас», «Хорове диригування», «Методика музичного виховання», «Виробнича педагогічна практика 3 музики». Сукупність цих навчальних курсів володіє резервами відпрацювання умінь і навичок вокального виконавства, рівень оволодіння якими засвідчує рівень набутого студентом вокально-виконавського досвіду. Комплексний вплив на формування означеного досвіду здійснюють подані вище функції мистецького навчання.

У той же час, якщо розглядати процес фахового навчання інтегративному контексті, то й інші навчальні курси, які безпосередньо не володіють резервами щодо провадження практичної вокально-виконавської діяльності, теж можуть бути залучені до набуття вокально-виконавського досвіду. Зокрема, музично-теоретичні курси «Вітчизняна та всесвітня історія музики», «Народознавство та музичний фольклор України», «Сольфеджіо», «Аналіз музичних творів», так само, як і курс «Концертмейстерський клас», що належить до сукупності дисциплін інструментальної підготовки, опосередковано можуть бути долучені до формування в студентів досвіду вокально-виконавської діяльності.

Метод педагогічного спостереження засвідчує, що студенти із задоволенням здійснюють музичну ілюстрацію лекційних занять з курсів «Вітчизняна та всесвітня історія музики», «Народознавство та музичний фольклор України», «Аналіз музичних творів», «Концертмейстерський клас», виконуючи романси, арії, народні пісні, які відповідають плануванню означених навчальних дисциплін. Адже почасту програмні вокальні твори на кшталт романсів Р.Шумана 3 циклу «Любов поета», арій 3 опер В.А.Моцарта «Весілля Фігаро», «Дон Жуан», українських народних пісень в обробках М.Лисенка, Л.Ревуцького, К.Стеценка тощо складають навчально-педагогічний репертуар студентів 3 «Постановки голосу» і систематично опрацьовуються. Таким чином, художня ілюстрація наведених вище навчальних курсів, здійснена за шляхом залучення вокально-виконавської діяльності, також сприяє формуванню в студентів факультетів мистецтв педагогічних університетів вокальновиконавського досвіду. 
На нашу думку, формування в майбутніх вчителів музичного мистецтва вокальновиконавського досвіду вимагає упровадження певних педагогічних орієнтирів у процес фахового навчання, серед яких: інтегративний підхід до навчального процесу у вищих музично-педагогічних навчальних закладах, який уможливлює формування вокальновиконавського досвіду не тільки під час вивчення студентами навчальних дисциплін, які володіють можливостями безпосередньої вокально-виконавської діяльності, але й під час засвоєння навчальних курсів, які володіють можливостями опосередкованої вокальновиконавської діяльності; привнесення у навчальні дисципліни, які не володіють можливостями безпосередньої вокально-виконавської діяльності, вокально-виконавського елементу, який може нести функціонально-ілюстративне навантаження, навантаження психологічної розрядки тощо; цілеспрямованість процесу фахового навчання майбутніх учителів музичного мистецтва на педагогічну мобілізацію всіх можливих резервів навчальних курсів щодо систематичного провадження музично-виконавської діяльності загалом і вокально-виконавської діяльності зокрема.

3 огляду на вищезазначене, доцільно визначити педагогічний потенціал фахового навчання майбутніх учителів музичного мистецтва щодо формування вокальновиконавського досвіду в якості комплексу педагогічних можливостей цього процесу, які оперують методичним інструментарієм щодо вмотивованості студентів у систематичному провадженні вокально-виконавської діяльності як основного джерела вокальновиконавського досвіду, а також акумулюють фонд знань, умінь і навичок, необхідних для розвитку інтелектуально-творчих особистісних якостей, що забезпечують стабільно якісний рівень вокального виконавства.

\section{Література}

1. Волинка Г.І. Вступ до філософії: історико-філософська пропедевтика: Підручник. К.: Вища школа, 1999. 624 с.

2. Гончаренко С.У. Український педагогічний енциклопедичний словник. Рівне: Волинські обереги, 2011. $552 \mathrm{c.}$

3. Крицький B.M. Педагогічні проблеми сучасної музично-виконавської підготовки студентів мистецьких спеціальностей // Наукова школа Г.М. Падалки. Колективна монографія. Київ: НПУ імені М.П. Драгоманова, 2011. 402 с., С. 199-202.

4. Мінаков М.А. Проблема досвіду в філософії Канта. - Мультиверсум. Філософський альманах. К.: Центр духовної культури, 2006. № 52 . - 187 с.

5. Павлова О.Ю. Естетичний досвід як онтологічна проблема: автореф. дисертації. доктора філософських. наук. Київ, 2009. 35с.

6. Падалка Г.М. Педагогіка мистецтва (Теорія і методика викладання мистецьких дисциплін) К.: Освіта Україна. 2008. 274 с.

7. Солонько Л. Феноменологія буттєвого досвіду // Науковий вісник Східноєвропейського національного університету імені Лесі Українки.- Луцьк: вид-во Східноєвропейського національного. університету ім. Лесі Українки, 2004. - № 16. С. 57-61.

8. Nierman G.E. The role of private music instruction in the development of high school music student's ability to describe musical events // Bull. Council Res. Music Education. 1983. - №73. P.15-27.

Про автора:

Гао Мін, аспірант кафедри теорії та методики музичної освіти, хорового співу і диригування факультету мистецтв імені Анатолія Авдієвського Національного педагогічного університету імені М.П. Драгоманова (Київ, Україна)

\section{Pedagogical potential of vocational training for forming vocal and performing experience of future music teachers}

Gao Ming

Relevance of the study. The article deals with the urgency of the problem of pedagogical potential of vocational training in the formation of vocal and performing experience in the context of improving the quality of art education in order to give future teachers of music art more qualification, which includes the 
presence of young professionals with professional experience in general and vocal performance. It is stated that vocal and performing experience allows the future teacher-musician to perform vocal-choral work at the proper level, to lead various forms of organization of collective music of schoolchildren, as well as to be able to conduct his own educational vocal-performing activity. The modern tendency of increasing the urgency of the problematic of potentials and reserves of professional training of students of the faculties of arts of pedagogical universities for forming vocal and performing experience has been determined.

Purpose. The purpose of the article is to outline the research, theoretical substantiation and determination of the pedagogical potential of professional training of future music teachers for forming vocal and performing experience.

Research methods. On the basis of the analysis of scientific-theoretical literature, the concept of "vocalperforming experience" is specified as a personal-professional characteristic of the future teacher of music art, which synthesizes knowledge, skills and skills in the field of vocal performance, ability to evaluate and reflexively analyze the results as one's own activity, as well as concert performances by other vocalists, as well as the ability to account for and correct mistakes.

Results. It is established that the pedagogical potential of professional art education involves the functions of such artistic education as motivational and educational, cultural, cognitive, hedonistic, communicative, creative and stimulating, as well as the function of psychological detachment. It is stated that the formation of future vocal teachers of vocal-performing experience requires the introduction of pedagogical guidelines in the process of vocational training, including: an integrative approach to the educational process in higher music-pedagogical educational institutions, which allows the formation of vocal and vocational training students of educational disciplines who have the ability to directly vocal performance, but also during the acquisition of training courses that possess consciousness indirectly vocal and performing activities; introducing into the disciplines that do not have direct vocal and performing activities, a vocal and performing element that can carry functional and illustrative load, psychological discharge, etc.; the purposefulness of the process of professional training of future music teachers to pedagogically mobilize all possible reserves of training courses on the systematic conduct of music-performing activities in general and vocal-performance activities in particular.

Conclusions. The pedagogical potential of professional training of future music teachers in forming vocal and performing experience as a complex of pedagogical possibilities of this process, which operate with methodical tools on motivation of students in the systematic conducting of vocal and performing activity as the main source of vocal acoustic, skills and skills necessary for the development of intellectually creative personality traits that provide consistently high quality level of vocal performance.

Keywords: complex of pedagogical opportunities; experience; functions of professional training; students of the faculties of arts of pedagogical universities; pedagogical guidelines; vocal-performing activity.

\section{References}

1. Volynka H.I. Vstup do filosofii: istoryko-filosofska propedevtyka: Pidruchnyk. K.: Vyshcha shk., 1999. 624 s. [in Ukrainian]

2. Honcharenko S.U. Ukrainskyi pedahohichnyi entsyklopedychnyi slovnyk. Vydannia druhe, dopovnene / Semen Ustymovych Honcharenko. - Rivne: Volynski oberehy, 2011. 552 s. [in Ukrainian]

3. Krytskyi V.M. Pedahohichni problemy suchasnoi muzychno-vykonavskoi pidhotovky studentiv mystetskykh spetsialnostei // Naukova shkola H.M. Padalky. Kolektyvna monohrafiia. Kyiv: NPU imeni M.P. Dragomanova, 2011. 402 s., S. 199-202. [in Ukrainian]

4. Minakov M.A. Problema dosvidu v filosofii Kanta. - Multyversum. Filosofskyi almanakh. / M.A. Minakov. - K.: Tsentr dukhovnoi kultury, 2006. - № 52. - 187 s. [Minakov M.A. The problem of experience in Kant's philosophy. - Multiversum. Philosophical almanac]. [in Ukrainian]

5. Pavlova O.Iu. Estetychnyi dosvid yak ontolohichna problema: avtoref. dys. d-ra filos. nauk / O.Iu. Pavlova. - Kyiv, 2009. 35 s. [in Ukrainian]

6. Padalka H.M. Pedahohika mystetstva (Teoriia i metodyka vykladannia mystetskykh dystsyplin). K. : Osvita Ukraina. 2008. 274 s. [in Ukrainian]

7. Solonko L. Fenomenolohiia buttievoho dosvidu // Naukovyi visnyk Skhidnoievropeiskoho natsionalnoho universytetu imeni Lesi Ukrainky.- Lutsk: vyd-vo Skhidnoievropeiskoho nats. universytetu im. Lesi Ukrainky, 2004. - № 16. S. 57-61. [in Ukrainian]

8. Nierman G.E. The role of private music instruction in the development of high school music students ability to describe musical events // Bull. Council Res. Music Education. 1983. №73. P.15-27.

About the author:

Gao Ming, postgraduate student at the Faculty of Arts, National Pedagogical Dragomanov University (01054, Kyiv, Ukraine) 